\title{
A FUNÇÃO DA ARTE E DA EDUCAÇÃO ESCOLAR A PARTIR DE GYÖRGY LUKÁCS E DA PEDAGOGIA HISTÓRICO-CRÍTICA ${ }^{1}$
}

\author{
Mariana de Cássia Assumpção ${ }^{2}$ \\ Newton Duarte ${ }^{3}$
}

\begin{abstract}
RESUMO
O objetivo deste artigo é investigar as principais categorias presente nas obras estéticas do filósofo húngaro György Lukács e estabelecer, a partir disso, relações com as premissas da pedagogia histórico-crítica. Tanto nas análises estéticas quanto nas pedagógicas buscamos destacar as aproximações entre arte e a educação escolar, evidenciando que a relação de ambas com as transformações sociais se dá por meio de sua ação sobre o desenvolvimento da subjetividade dos indivíduos. A técnica adotada para o presente estudo foi a de pesquisa bibliográfica, onde utilizamos como fontes principais as obras estéticas de Lukács e aquelas situadas no âmbito da pedagogia histórico-crítica.

Palavras-chave: arte; educação escolar; György Lukács; pedagogia histórico-crítica.
\end{abstract}

\section{THE FUNCTION OF ART AND EDUCATION SCHOOL FROM GYÖRGY LUKÁCS AND HISTORICAL-CRITICAL PEDAGOGY}

\begin{abstract}
The aim of this paper was to investigate the major categories in this aesthetic works of the Hungarian philosopher György Lukács and establish, from that, relations with the premises of the historical-critical pedagogy. Both aesthetic analysis as in pedagogical seek to highlight the similarities between the function of art and the role of school education in order to show that both have connections with social transformations by means the action on the development of the subjectivity of individuals. This study is based on a bibliographic research which had as main sources the aesthetic works of György Lukács and works written by educators from the perspective of historical critical pedagogy.

Keywords: art; school education; György Lukács; historical-critical pedagogy.
\end{abstract}

\section{Introdução}

György Lukács nasceu em Budapeste (Hungria) em 1885 e faleceu em 1971. Podemos situá-lo entre os grandes pensadores marxistas do século XX. No decorrer de sua trajetória, Lukács debruçou-se sobre os clássicos da filosofia e não hesitou em revisitar seus pressupostos teórico-metodológicos. Superou influências idealistas avançando na compreensão materialista histórica e dialética da realidade social e da arte (KIRALYFÁLVI, 1975); (TERTULIAN, 2008); (FREDERICO, 2005).

A arte é o resultado de um longo processo de desenvolvimento da humanidade, no qual a atividade humana, além de gerar produtos que atendessem às necessidades básicas de existência, também gerou necessidades não materiais e os objetos de sua satisfação. Não estamos, com isso, estabelecendo qualquer separação entre atividade material e não material. Toda atividade humana contém a unidade entre matéria e ideia, ou entre o material e o ideativo. Mas os produtos da atividade podem ser preponderantemente materiais, embora contenham elementos ideativos, ou preponderantemente ideativos, embora contenham elementos materiais ${ }^{4}$. No conjunto dos produtos não materiais que a 
humanidade produziu a arte se coloca, de acordo com Lukács (1966a, 1966b, 1967a, 1967b, 1970), como uma forma peculiar de reflexo da realidade que difere das formas pelas quais essa mesma realidade é refletida, por exemplo, na consciência cotidiana e na ciência.

\begin{abstract}
A arte reflete a realidade, mas de um modo próprio. Com os seus recursos, ela apresenta uma reprodução fiel da realidade, mais rica do que aquela vivida e sentida pelo homem imerso na vida cotidiana. A partir dessa diferenciação, Lukács insiste no papel educativo da arte, sua capacidade de enriquecer a visão de realidade que se encontra fragmentada na cotidianidade (FREDERICO, 2005, p. 87).
\end{abstract}

A obra de arte é uma forma de objetivação da subjetividade humana e tem como uma de suas características a evocação de sentimentos. Tais evocações incidem sobre a consciência, produzindo efeitos sobre a maneira como os indivíduos se relacionam afetiva e cognoscitivamente com a realidade humana. sujeitos:

Aliás, Lukács defende que a arte teria por finalidade principal a de agir sobre os

A arte opera diretamente sobre o sujeito humano; o reflexo da realidade objetiva, o reflexo dos homens sociais em suas relações recíprocas, no seu intercambio social com a natureza, é um elemento de mediação, ainda que indispensável; é simplesmente um meio para provocar este crescimento do sujeito. (LUKÁCS, 1970, p. 274).

A pedagogia histórico-crítica, por sua vez, considera como elemento primordial na educação o papel desempenhado pelo professor e a sua função de transmitir, a cada aluno, o saber sistematizado (SAVIANI, 2008) produzido pelo gênero humano no decorrer da história. Esse processo de reconhecimento da cultura como produção imanente à atividade humana desencadeia o desenvolvimento da consciência, sem o qual não ocorre a humanização dos indivíduos.

Trata-se do processo dialético caracterizado por Saviani (2007, p. 3), como passagem do senso comum à consciência filosófica, processo esse que não é simples nem rápido, uma vez que implica: “[...] passar de uma concepção fragmentária, incoerente, desarticulada, implícita, degradada, mecânica, passiva e simplista a uma concepção unitária, coerente, articulada, explícita, original, intencional, ativa e cultivada".

$\mathrm{Na}$ linha dos estudos realizados por Duarte (2008) em sua pesquisa "Arte e Formação Humana em Lukács e Vigotski”, apresentamos neste artigo algumas reflexões sobre o papel mediador da arte em Lukács e o papel mediador da educação escolar na pedagogia histórico-crítica, a partir da dissertação de mestrado de Assumpção (2014).

\title{
György Lukács e o objeto estético
}

Lukács analisou a arte como um modo específico de reflexo da realidade objetiva. Nesta primeira e sucinta definição é possível detectar a fundamentação marxista de sua estética, uma vez que ele partiu do pressuposto de que o conhecimento do mundo externo resulta de um reflexo, na consciência dos indivíduos, da realidade que existe independentemente deles. A forma artística de reflexo da realidade precisava ser investigada nos seguintes termos: 
[...] a obra de arte é algo particular, mas de um duplo ponto de vista. Por um lado, cria um "mundo próprio", em si concluído. Por outro, naturalmente, age num sentido análogo: assim como o caráter particular da obra agia sobre o processo criador, sobre a personalidade do criador, transformando-a, assim também, quando de sua eficácia, ela deve influenciar do mesmo modo aquele que a recebe. Dado que objetivamente - as individualidades das obras em si concluídas, autosuficientes, não são mundos entre si separados definitiva e solipsisticamente, mas que remetem, ao contrário, precisamente por esta sua autonomia, à realidade que refletem em comum, a mais intensa eficácia por um destes "mundos próprios" e particulares não deve subjetivamente - consolidar quem o recebe em sua mera particularidade, mas ampliar seus horizontes, colocá-lo em relações mais estreitas e ricas com a realidade. (LUKÁCS, 1970, p. 240-241).

Tendo como referência a citação acima, destacamos as principais características da estética lukacsiana. O primeiro ponto que merece atenção é o de que a maneira estética de reflexo da realidade objetiva foi denominada como mimese. Esta palavra etimologicamente significa imitação. Embora a arte seja uma forma de reflexo que, portanto, imita a realidade, não se deve concluir daí que a estética se restringe a reproduzir a realidade de maneira mecânica, passiva ou natural, tal como ela aparece de imediato aos indivíduos imersos no cotidiano. A mimese artística é uma forma de representação dos aspectos mais importantes de uma determinada realidade.

Inicialmente podemos até deduzir que a arte trabalha apenas com a aparência, mas por trabalhar as aparências dando-lhes uma forma e um conteúdo artísticos adequado há o desvelamento da essência (DUARTE et al., 2012). A arte trabalha com a unidade de essência e aparência. Para Lukács (1966b) o fato da arte ser um reflexo mimético da realidade significa que ela se volta necessariamente à vida dos seres humanos, esforçandose para despertar a totalidade humana, e provocar, por meio do seu reflexo, uma percepção mais ampla e enriquecida da prática social.

Segundo Tertulian (2008, p. 251), a arte visa conservar "a objetividade do mundo em si, inalterada pelas ilusões ou pelos preconceitos, mas evocá-la exclusivamente em função da ampliação e fortalecimento da subjetividade". Isso não quer dizer que a arte deva expressar apenas figuras humanas ou abordar temas relacionados com a dinâmica entre o modo de produção e os indivíduos de uma época. A determinação humana que a arte encerra pode ser verificada, até mesmo, em objetos estéticos que representam, por exemplo, elementos da natureza. Nesse caso, tratar-se-á de uma obra verdadeira se ela expressar uma significação social incidindo sobre a subjetividade dos indivíduos.

Lukács (1966a) assegura que um dos pontos mais importantes de sua investigação foi a tentativa de entender como os aspectos da vida cotidiana retratados nas obras de arte levam os indivíduos a uma reflexão mais acurada e, sobretudo, mais crítica sobre a vida da humanidade.

É preciso destacar que a realidade representada pela arte se identifica, até certo ponto, com o cotidiano ao mesmo tempo em que o supera.

Enquanto produto de uma atividade peculiar da sociedade, enquanto forma que as pessoas têm para se relacionar com o mundo ao redor, as obras de arte contribuem necessariamente para o desenvolvimento social: surgem com a tarefa de satisfazer necessidades da vida e para ela regressam, tornando-as, assim, mais rica, mais ampla, mais diferenciada e 
a elevam a níveis superiores de desenvolvimento. (CHICOTE, 2014, p. 104).

A arte se liga ao particular, ela elege traços presentes no cotidiano, mas que muitas vezes estão esmaecidos, por se reduzirem, com frequência, a uma utilidade prática imediata, basta pensar no ritmo que embala os relógios ou nas medidas proporcionais necessárias ao trabalho artesanal. A arte verdadeiramente grande deve retirar tais elementos do contexto cotidiano dando-lhes forma e conteúdo artísticos, ou seja, deve reelaborá-los.

A pergunta que se coloca é como provocar essa transformação, esse salto qualitativo que transforma os elementos da vida em elementos estéticos? Isso acontece a partir da intensificação qualitativa e quantitativa dos traços que no cotidiano são obscurecidos. Eis, aqui, a especificidade do reflexo estético. Ao acentuar os aspectos aparentes da relação entre os seres humanos e destes com a sociedade, a obra de arte faz com que o sujeito ultrapasse o nível do seu ser tomado individualmente, caminhando em direção ao contato com a essência da humanidade.

Essa reelaboração será, de fato, estética se produzir no indivíduo receptor e criador um confronto com aspectos alienantes da cotidianidade, provocando uma elevação dessas subjetividades à autoconsciência do gênero humano. A esfera estética deve ser entendida como um reflexo que está condicionado ao aqui e agora histórico e, ao mesmo tempo, encerra uma totalidade com características e leis singulares. Uma obra literária, por exemplo, é construída a partir de uma unidade de tempo, ação e lugar, ou seja, ela deve possuir um enredo único, com personagens que passam por emoções específicas e cujos movimentos desencadeiam situações também peculiares.

A arte, ao reforçar os aspectos de um período histórico no interior de um enredo sistematicamente elaborado, tende a distanciar-se do cotidiano imediato.

Deste modo, a individualidade da obra de arte - precisamente como expressão da realidade - pode superar em intensidade a realidade imediata, se bem que, no processo criativo da aproximação, jamais a arte possa esgotá-la inteiramente. $O$ fato de que a obra não atinja, mas ao mesmo tempo, supere a realidade constitui uma contradição, portanto, mas uma contradição viva e vivificadora da vida da própria arte. (LUKÁCS, 1970, p. 230-231).

Embora os gêneros artísticos possuam suas peculiaridades e, aparentemente se mostrem fechados em um mundo exclusivo, é por meio desses traços particulares devidamente acentuados que eles congregam o potencial de provocar a ascensão da consciência do indivíduo acima do nível da cotidianidade. Deve-se entender, portanto, que, se por um lado, cada obra é única, pois cada uma apresenta elementos próprios que constituem o seu "mundo", por outro lado esse microcosmo se edifica por meio de relações mediatas com a prática social.

A obra de arte é produto humano e nela está concretizada a característica essencial do ser humano, qual seja: a capacidade de transformar intencionalmente a natureza e a si mesmo, de produzir ao longo do processo histórico um mundo social. A arte é, pois, uma forma da humanidade se colocar diante de si própria como um objeto externo, é uma possibilidade de vivenciar, de forma condensada e intensificada, os grandes dramas da história.

O indivíduo criador e receptor deve suspender as atividades cotidianas para ter contato autêntico com as obras de arte. O próprio conteúdo por elas expressado aproxima- 
se e diferencia-se do habitual. Por isso, o critério que permite distinguir as obras de arte mais desenvolvidas é o de quanto o objeto estético traduz a riqueza da realidade cultural como uma realidade produzida histórica e socialmente pelo conjunto dos seres humanos.

A arte constrói seu reflexo de modo a proporcionar a cada indivíduo uma relação consciente com aquilo que o caracteriza e o faz sentir parte do gênero humano. Mesmo quando a arte retrata o mundo das coisas, o mostra como coisas humanas. Nesse sentido, por um lado, a arte desfetichiza a realidade, tirando das coisas a aparência de vida própria e, por outro, dá à vida humana a forma de objetos, os objetos estéticos, possibilitando aos indivíduos se apropriarem artisticamente de uma vida que não é sua, experimentarem, emoções que provavelmente não seriam disponibilizadas em seu cotidiano.

O efeito da obra de arte será desencadeado tão somente quando o objeto estético for submetido à percepção subjetiva, ou seja, a arte existe na relação que se estabelece com o indivíduo. A obra de arte é genuinamente artística na medida em que suscita algum efeito, caso contrário, um quadro é apenas um quadro que carrega uma materialidade específica (no caso, seria a tinta empregada na pintura, o pano da tela etc.). Em se tratando de arte, o objeto existe como objeto estético, propriamente dito, enquanto está em relação com a subjetividade, evocando vivências e tornando possível à apreensão de aspectos relacionados à existência do ser humano como um ser genérico.

$\mathrm{Na}$ arte, a esfera subjetiva configura-se como veículo indispensável para se alcançar o reflexo objetivo do real, isto é, a subjetividade faz-se essencial para o efeito que a obra venha a provocar. A relação entre objetividade e subjetividade e a contradição do reflexo estético reside em "[...] captar todo objeto e, acima de tudo, a totalidade dos objetos sempre em conexão, embora não explicita e diretamente dita, com a subjetividade humana" (LUKÁCS, 1966b, p. 237).

Diferentemente da arte, a objetividade científica busca decifrar as leis que regem os fenômenos do real, sem estabelecer, para tanto, um vínculo direto com a subjetividade. Assim como a arte, também o conhecimento científico aparece, no percurso da história humana, em luta contra o antropomorfismo tanto do cotidiano como das elaborações religiosas. Porém, ao se dedicar à apreensão dos postulados e da lógica que dirige o real, a ciência configura-se como um reflexo desantropomorfizador da realidade. "A intenção de refletir, de modo tão adequado quanto possível, as propriedades e relações dos fenômenos, a purificação dos conhecimentos de todo traço de subjetividade [...] conferem a ciência o caráter de reflexo desantropomorfizante do mundo" (TERTULIAN, 2008, p. 205, grifo do autor).

Poderia ser questionado se o fato da ciência ser desantropomorfizadora significaria que esse tipo de reflexo da realidade privilegiaria a razão em detrimento da emoção e da sensibilidade. Aqui é fundamental frisar que apesar de seu caráter desantropomorfizador, a objetividade científica também se volta ao ser humano.

[...] o reconhecimento de leis da realidade em si, independentes da consciência humana, se converte aqui em veículo da consciência da consecução da liberdade do homem, de sua liberdade como penetração intelectual nas forças reais objetivas que apenas pode ter mediante um conhecimento adequado, para desmascarar aquelas outras forças imaginárias, inconscientemente produzidas pelo homem mesmo e que este não poderá superar senão mediante tal esclarecimento da sua essência. (LUKÁCS, 1966a, p. 184).

Afirmar que a ciência lida apenas com a racionalidade é negar e unilateralizar a relação sujeito e objeto. Tanto a ciência quanto a arte conclamam os aspectos afetivos e 
cognitivos dos indivíduos. Entretanto, como se evidenciou, essas duas formas de reflexo do real possuem características distintas, cabendo à arte destacar o sensível, ao passo que a ciência precisa desviar-se dos elementos subjetivos para captar os fenômenos com a necessária objetividade. Os fenômenos do real não seriam desvelados cientificamente caso não houvesse, da parte do sujeito, certo envolvimento em relação ao seu objeto de investigação.

O desenvolvimento da faculdade de pensar por meio de conceitos não acarreta a atrofia da faculdade de sentir: o homem se humaniza tanto no raciocínio como na sensibilidade. Pensando as coisas de maneira mais correta, eles as compreendem melhor e pode senti-las com maior profundidade. E, desenvolvendo a sua capacidade de senti-las correta e claramente, enriquecerá a sua reflexão a respeito delas. $\mathrm{O}$ avanço da consciência teórica já alcançada em nossa época provocou, nos aspectos que mais interessam à nossa práxis, um enriquecimento da percepção sensível dos homens. (KONDER, 2013, p. 39, grifo do autor).

Não se trata, portanto, de se contrapor ciência e arte, a partir de concepções dicotômicas que separam razão e emoção, reduzindo a ciência a uma visão reducionista da razão e a arte a uma visão igualmente reducionista da sensibilidade afetiva.

\section{A função da arte na formação dos indivíduos}

A catarse é outra categoria empregada por Lukács (1966a). Ela se refere, em linhas gerais, ao ápice da relação entre o sujeito e o objeto estético, num processo de elevação acima do caráter pragmático e heterogêneo que caracteriza a subjetividade dos indivíduos nas atividades próprias à vida cotidiana.

Este é um processo, muitas vezes, moroso que depende da educação estética para atingir êxito. Um sujeito educado esteticamente, que possui uma sensibilidade apurada tem maiores possibilidades de captar toda a riqueza de uma obra de arte e vivenciar essa riqueza como parte de sua própria vida.

Sermos educados pela Arte implica a vivência de determinadas emoções, das reações estéticas, que não se apresentam sobre a mesma qualidade que as emoções suscitadas por outros estímulos. [...] Também implica se ter acesso à condicionalidade sócio-histórica em que se encontram os indivíduos produtores, criadores, fruidores e aqueles que estão alheios à Arte, bem como os próprios produtos ou produções. (BARROCO, 2009, p. 126).

A discussão sobre a formação da sensibilidade humana remete à educação em geral e, mais especificamente, à escola. É no ambiente escolar que as artes mais ricas devem ser ensinadas. Assim, os indivíduos vão aos poucos desenvolvendo a sensibilidade, tornandose indivíduos educados esteticamente e capazes de atingirem a catarse.

A postura contrária à arte e ao processo catártico que se desencadeia por meio da apropriação dos elementos culturais pode ser analisada no âmbito educacional, em especial, no que tange a algumas teorias pedagógicas que negam o ato de ensinar e defendem um currículo escolar esvaziado dos conteúdos artísticos, científicos e filosóficos (DUARTE, 2000). Essas teorias, ao negarem às novas gerações da classe trabalhadora o acesso a tais bens, carregam uma atitude hostil em relação a certas formas de conhecimento e, mesmo não necessariamente tendo consciência disso, um receio dos seus 
possíveis efeitos em relação à transformação qualitativa da visão de mundo (DUARTE, 2015).

Em termos de luta de classes, os dominantes não visam sair da sua posição em prol dos dominados. Por essa razão, no limite, na sociedade capitalista, não se alcançará a plena socialização do saber sistematizado pelo sistema escolar (SAVIANI; DUARTE, 2012), já que tal socialização produziria, ao menos potencialmente, as condições para que os indivíduos da classe dominada passassem a formular questionamentos sobre a ordem social capitalista. Mas a pedagogia histórico-crítica defende que é possível e necessário uma atuação coletiva e individual dos educadores no sentido de se explorarem as contradições próprias à sociedade burguesa, fazendo, dessa forma, que a educação escolar avance em direção ao horizonte da plena socialização do saber sistematizado. Nesse sentido, é fundamental ter como objetivo promover a catarse por meio do ensino dos conteúdos artísticos, científicos e filosóficos.

A catarse possui um efeito momentâneo de elevação da singularidade do indivíduo, isto é, esse processo "purificador" guarda o potencial de enriquecer a subjetividade. Isso significa, voltando novamente à esfera estética, que esta não busca atingir um fim imediato na prática social, mas sim atuar sobre a subjetividade dos indivíduos.

A arte opera diretamente sobre o sujeito humano; o reflexo da realidade objetiva, o reflexo dos homens sociais em suas relações recíprocas, no seu intercambio social com a natureza, é um elemento de mediação, ainda que indispensável; é simplesmente um meio para provocar este crescimento do sujeito. (LUKÁCS, 1970, p. 274).

Se a arte está diretamente voltada ao sujeito ela relaciona-se, portanto, de modo indireto e mediado com a prática social. Um traço essencial da estética lukacsiana é a tentativa de explicar que os efeitos desencadeados pela arte não se verificam direta nem imediatamente na prática social, uma vez que tais efeitos se instalam no âmbito do processo formativo dos indivíduos.

O efeito da obra de arte se dá em termos das relações entre a subjetividade dos indivíduos e sua condição de pertencimento ao gênero humano e, nesse sentido, a obra artística pode influenciar a vida cotidiana, porém, de modo indireto. A arte e também a ciência fazem com que o indivíduo se afaste momentaneamente do fluxo da prática social, se desprenda da imediatez, da espontaneidade e do pragmatismo do cotidiano, atingindo, desse modo, um meio homogêneo. Este meio homogêneo se estrutura, como ratifica Lukács (1966b, p. 329), a partir de uma "suspensão temporária de toda a finalidade prática". Apesar de não se verificarem de imediato, os efeitos estéticos ocorrem e são, sobretudo, humanizadores e enriquecedores da visão de mundo dos indivíduos.

A finalidade do reflexo estético é, em primeiro lugar o de incidir na subjetividade, e por intermédio dessa ação sobre a subjetividade, agir sobre a prática social.

Se, pois, a obra exerce um efeito evocador, esse efeito tem que conter consciente ou inconsciente direta ou talvez, muito mediatamente - o despertar de sua tomada de partido. Mas a força e a profundidade reais da evocação artística se dirigem acima de tudo à interioridade do indivíduo: o que ocorre acima de tudo é o despertar de novas vivências no indivíduo, as quais ampliam e aprofundam sua imagem de si mesmo, do mundo com o qual tem que se defrontar no sentido mais amplo da palavra (LUKÁCS, 1966b, p. 334). 
Lukács (1966a) considera a arte como uma das formas de reflexo da realidade objetiva, sem que isso signifique, entretanto, que a obra expresse direta e necessariamente a concepção de sociedade do sujeito criador. Sua subjetividade é, sem dúvida, decisiva no ato de produção artística e se objetiva na obra. Mas essa subjetividade, como captação artística da realidade, pode ser mais rica e desenvolvida do que as ideias que o artista propôs sobre a realidade social e até mesmo sobre as relações entre arte e prática social. Nesse sentido, pode inclusive haver uma contradição entre as posições que o indivíduo artista toma em relação à sociedade e as posições que estão contidas nas obras que ele produz. Essa reelaboração, pela subjetividade do artista, do material coletado da realidade, produz uma reconfiguração que promove uma ampliação e uma intensificação de emoções e ideias no indivíduo receptor. A arte, portanto, reflete dialeticamente a realidade produzindo tomadas da posição, tomadas de partido em face dos problemas sociais.

Nesse sentido, a prática artística não é neutra. Porém, é preciso ficar claro que as relações entre história e estética não são relações de causa e efeito. A arte possui também uma autonomia relativa no que tange às determinações sociais. Não se pode afirmar que uma obra de arte será autêntica apenas quando abordar temas relacionados à luta de classes, à desigualdade presente na sociedade capitalista, à exploração do trabalho. Ao se debruçar sobre outros aspectos da vida humana, captando o seu núcleo, a obra de arte indiretamente contribui para o engajamento ético-político, para a reflexão crítica da realidade, pois atua sobre o indivíduo da prática, ampliando a sua consciência e desenvolvendo sua subjetividade.

As relações entre o artista e sua obra não devem ser analisadas apenas sob o ponto de vista do momento histórico da criação (LUKÁCS, 2009). Limitar-se ao contexto social e às convicções do sujeito criador é simplificar as possibilidades que a arte encerra. No centro a partir do qual o estudo estético deve se desenrolar, está a própria obra de arte.

Um bom artista, mesmo que não tenha plena consciência disso, é um artista realista, pois, de alguma forma, ele se propõe a investigar a realidade e a exprimi-la, captando suas contradições essenciais, promovendo uma compreensão mais profunda da dinâmica do real. Tertulian (2002, p. 15), referindo-se à originalidade da Estética de Lukács, afirma [...] "que para ele o caráter lírico e o caráter mimético da arte [...], longe de estarem em lugares opostos, formam uma unidade indissociável. O realismo é para Lukács uma qualidade construtiva da grande arte, sempre e em todos os lugares".

Em primeiro plano, as objetivações artísticas contribuem para o desenvolvimento sensível e intelectual de cada sujeito a partir da apropriação, em um nível mais elevado, das contradições da história humana e por consequência, favorece as condições para a tomada de consciência da possibilidade de modificação de si mesmo e da realidade.

A arte, assim como todas as formas de atividade humana nas sociedades marcadas pela luta de classes, está subordinada aos processos alienantes, contudo ela pode incidir indiretamente sobre a base das relações sociais de produção, na medida em que se volta a desfetichização da realidade humana refletida na consciência dos indivíduos que atuam na prática social. Antígona, Hamlet e Don Quixote são personagens da literatura que "[...] podem exercer uma forte influência sobre as possibilidades de ação" (KOFLER; ABENDROTH; HOLZ, 1969, p. 36).

Na sequência do artigo explicamos com maiores detalhes o método de ensino da pedagogia histórico-crítica, pois consideramos que a partir dele é possível compreender as relações entre a função da educação escolar e a realidade social. Além disso torna-se mais fácil visualizar as aproximações entre o papel da arte e a educação na perspectiva da pedagogia histórico-crítica. 


\section{O método de ensino da pedagogia histórico-crítica e as relações entre a função da arte e da educação.}

A pedagogia histórico-crítica considera a prática educativa como parte da prática social em sua totalidade, mas uma parte que tem uma peculiaridade, a de ser uma mediação cuja especificidade reside na socialização do saber sistematizado. (SAVIANI, 2009). Em texto recente em que explora o conceito dialético de mediação na pedagogia históricocrítica, Saviani (2014) alerta para a necessidade de se evitar uma concepção linear e reducionista do método por ele preconizado. Como é sabido, a prática social é tomada nesse método como o primeiro e o último daqueles que seriam os cinco momentos do método. Entre eles estariam os da problematização, da instrumentalização e da catarse. Nossa interpretação é a de que não se trata, como alguns interpretam, de uma sequência de passos que deveriam ser usados para o planejamento de uma aula que, nessa interpretação, partiria de um problema da prática social cotidiana dos alunos, buscaria os instrumentos intelectuais para enfrentamento desse problema, levaria à incorporação desses instrumentos à dinâmica psíquica dos alunos (a catarse) e voltaria à prática social para resolução do problema em questão. Esse tipo de interpretação do método didático da pedagogia histórico-crítica assemelha-se ao método de ensino por projetos, ou pedagogia dos projetos, adotando uma visão da prática social limitada ao âmbito da cotidianidade. Como analisamos nos itens anteriores deste artigo, as produções humanas mais elevadas nos campos da ciência, da arte e da filosofia têm como uma de suas características a de ultrapassarem os limites do pragmatismo e do imediatismo da vida cotidiana.

Afirmar que a prática social e sua problematização está no ponto de partida da prática pedagógica significa afirmar, como explica Saviani, que em última instância o que se busca é a superação da visão sincrética que o aluno tenha da sociedade na qual ele está inserido, ou seja, que ele desenvolva uma visão crítica da sociedade capitalista:

\footnotetext{
Portanto, assumir essa orientação pedagógica na atividade educativa significa ter presente o modo como está estruturada a sociedade atual no interior da qual os educandos nasceram. Cabe, portanto, educá-los para viver nessa sociedade, o que implica conhecê-la o mais profundamente possível. E conhecer significa não apenas deter informações, mas compreender as relações, compreender as determinações que se ocultam sob as aparências dos fenômenos que se manifestam empiricamente à nossa percepção. Conhecer implica, então, captar o movimento que nos permite entender como nasceu essa sociedade; de onde ela surgiu; como se encontra estruturada; quais as contradições que a movem definindo as tendências de seu desenvolvimento e apontando para as possibilidades de sua transformação numa nova forma de ordem superior, que somente poderá ser instaurada pela ação efetiva, intencional e organizada das forças sociais que hoje se encontram subjugadas e, por isso, têm todo o interesse e buscam lutar para mudar as condições vigentes e instaurar outro tipo de sociedade em que as relações entre os homens encaminhem coletivamente o pleno desenvolvimento das forças produtivas humanas em benefício de toda a humanidade. (SAVIANI, 2015, p. 36)
}

A prática social não se refere às ações realizadas por um indivíduo, mas sim pelas atividades desempenhadas pelo conjunto dos seres humanos, bem como à estrutura da sociedade na qual os sujeitos - no caso específico de análise, professores e alunos sintetizam concreta e objetivamente as relações sociais, sendo a prática pedagógica uma das várias dimensões que compõe a tessitura da prática social mais ampla. 
Já a atividade refere-se ao "ato ou conjunto de atos em virtude do qual um sujeito ativo (agente) modifica uma determinada matéria prima [...]. A atividade mostra, nas relações entre as partes e o todo, os traços de uma totalidade concreta" (VÁZQUEZ, 1977, p. 186). Acontece, porém - e aqui reside o grau de dependência entre os dois conceitos que a realidade histórica gera necessidades as quais serão satisfeitas à medida que incitam os indivíduos a agirem, mobilizando suas capacidades, no processo de criação de mediações para atender as demandas que lhes são colocadas pela prática social.

Tem-se, assim, a partir da relação entre as circunstâncias delineadas pela estrutura social e a atuação dos indivíduos sobre elas, a possibilidade de construção da realidade e de reprodução dos seres humanos, em um processo de transformação dialética. Em linhas gerais, a intervenção do ser humano sobre a realidade não se dá imediatamente, uma vez que requer do indivíduo um posicionamento consciente e, portanto, um relativo distanciamento da realidade com vistas a uma prática efetiva e transformadora.

Não existem práticas sociais distintas, uma para o professor e outra para o aluno. Porém, há formas qualitativamente distintas de compreensão dessa prática, pois o aluno está na condição de quem aprende e o professor na de quem ensina. Se a criança no primeiro momento da prática educativa, lida com os fenômenos do mundo de forma caótica e sincrética o professor, a princípio, possui uma compreensão mais sistemática da realidade.

Apesar do professor ter incorporado os conhecimentos necessários, haverá sempre outros elementos a serem analisados e apropriados, pois a apreensão do real nunca se esgota. Por essa razão Saviani (2015, p. 35) afirma que o professor no primeiro momento da prática pedagógica possui uma "síntese precária". Essa síntese é precária tanto pelo fato do professor, no início do processo educativo, não conhecer ainda concretamente os indivíduos alunos que tem diante de si, como pelo fato de que o professor precisa constantemente avançar em suas próprias aprendizagens, em seu domínio dos conhecimentos científicos, artísticos e filosóficos, bem como em seu posicionamento perante as contradições da sociedade capitalista.

Mas afirmar que neste primeiro momento o professor é uma síntese precária e o aluno é uma síncrese caótica não significa, de modo algum, que a pratica educativa permanecerá num nível mais próximo do cotidiano. É necessário entender que esse é apenas o primeiro momento para que o trabalho educativo forneça as condições indispensáveis à passagem de uma concepção de mundo heterogênea do cotidiano para uma concepção sistemática da realidade.

Verifica-se a necessária desigualdade de nível cognitivo entre professor e aluno e é nesse sentido que a pedagogia histórico-crítica enfatiza a prioridade da transmissão de conhecimento pelo professor. Antonio Gramsci, ao fazer a crítica às concepções educacionais que consideram que a instrução (ensino) não educa, afirma que a relação entre instruir (ensinar) e educar precisa ser compreendida a partir da ação do professor:

[...] na escola, o nexo instrução-educação somente pode ser representado pelo trabalho vivo do professor na medida em que o mestre é consciente dos contrastes entre o tipo de sociedade e de cultura que ele representa e o tipo de sociedade e de cultura representado pelos alunos, sendo também consciente de sua tarefa que consiste em acelerar e em disciplinar a formação da criança conforme o tipo superior em luta com o tipo inferior. (GRAMSCI, 1982, p. 131).

No início professores e alunos estão em níveis diferenciados. Segundo Martins (2013), o fato do primeiro atuar no âmbito da lógica do ensino uma vez que esta é a sua 
função, ao passo que o aluno se insere na lógica da aprendizagem. Professor e aluno possuem funções distintas no interior da prática pedagógica, sendo que a atividade de cada um deles é operada de modo também diverso.

Na pedagogia histórico-crítica a lógica dialética do ensino caracteriza-se por partir "[...] do geral para o particular, do abstrato para o concreto, do não cotidiano para o cotidiano e, fundamentalmente, do conceito propriamente dito a serviço da compreensão e da superação da síncrese do aluno" (MARTINS, 2013, p. 294).

Já a lógica da aprendizagem caminha do "particular para o geral, do sensorial para o abstrato, da síncrese à síntese, do cotidiano para o não cotidiano" (MARTINS, 2013, p. 293). O trabalho do professor não deve submeter-se à lógica da aprendizagem, mas sim à do ensino. É, pois, a contradição entre esses processos que resulta no movimento necessário de ascensão e desenvolvimento da subjetividade para que os alunos alcancem níveis mais elevados de objetivação.

É por isso que a pedagogia histórico-crítica entende que os conteúdos escolares não são aqueles ligados ao cotidiano dos alunos, tal como defendem as teorias em voga na atualidade. Quanto mais próxima do cotidiano estiver a prática educativa mais intensamente ela reproduz a alienação presente na sociedade como um todo. A concepção pedagógica histórico-crítica por ser uma teoria marxista em educação afirma que o objetivo da educação escolar é o de promover uma permanente luta contra a alienação e, para tanto, defende o ensino dos conhecimentos mais desenvolvidos cuja apropriação dificilmente acontece sem a mediação da educação escolar. Teorias educacionais que se colocam a favor de conteúdos próximos ao cotidiano acabam atuando pela perpetuação do capitalismo, uma vez que negam à classe trabalhadora a possibilidade de se apropriar dos conhecimentos mais ricos já produzidos.

Em se tratando dos conhecimentos que devam ser transmitidos, além de seu caráter não cotidiano, a pedagogia histórico-crítica, aponta para a necessidade de que esses conhecimentos respondam aos problemas postos pela prática social da humanidade. Aqui vale fazer uma ressalva fundamental, pois a concepção de problema em pauta não é, como em outras perspectivas, limitada aos problemas imediatamente ligados à vida cotidiana dos alunos.

Saviani explica as concepções acerca da palavra problema e em um primeiro esclarecimento mostra que problema, do ponto de vista filosófico, não se refere necessariamente a uma indagação, pois "[...] uma questão, em si, não é suficiente para caracterizar o significado da palavra 'problema'. Isso porque uma questão pode comportar [...] resposta já conhecida” (SAVIANI, 2008, p. 13).

Problema também não é aquilo que se desconhece, pois, o fato de se ignorar algo, bem como "a aceitação da existência de fenômenos que ultrapassam irredutivelmente e de modo absoluto a nossa capacidade de conhecimento, nada disso é suficiente para caracterizar o significado essencial que a palavra 'problema' encerra" (SAVIANI, 2008, p.14-15).

Vê-se, portanto, que problema se vincula ao fato de que os fenômenos da vida se apresentam em sua aparência, sendo necessário (e aqui se explicita a concepção filosófica de problema) ultrapassar essa aparência em direção à essência. $\mathrm{O}$ ser humano situado historicamente tem a necessidade de conhecer o real para além das aparências, desenvolver suas funções psicológicas e, portanto, humanizando-se nesse processo. A educação escolar é o caminho indispensável para que isso aconteça.

As pedagogias hegemônicas na educação brasileira propagaram a ideia de que o processo educativo deve ter como eixo norteador os interesses dos alunos, pois assim 
procedendo, garante-se a harmonia no processo de aprendizagem, instituindo uma relação democrática entre professor e aluno.

No entanto, podemos inferir sobre quais são os possíveis interesses das crianças em idade escolar? Ora, certamente esses interesses se restringem aos elementos que constituem a esfera fortuita da vida cotidiana da qual fazem parte. Esse é, pois, o aluno empírico que "[...] se interessa por satisfações imediatas ligadas à diversão, à ausência de esforço, às atividades prazerosas" (SAVIANI, 2004, p. 49).

Não significa, entretanto, que o interesse do aluno não seja importante para o processo educativo, sem sombras de dúvidas o é. Acontece que o interesse está circunscrito a apenas uma parte do conjunto que institui o processo de aprendizagem. Este interesse tende a aumentar aos poucos conforme o aluno vai se apropriando do conhecimento.

Fundamentando-se em Luria, Martins (2013, p. 39) explica que um dos traços distintivos da atividade especificamente humana é o de que esta:

[...] se desprende dos limites das necessidades biológicas e, mesmo ao visar atendê-las, o faz vinculando-as a outras e mais complexas necessidades. Assim, regendo-se por motivos humanos, construídos na atividade que possibilita o "encontro" entre dado estado carencial (necessidade) e o objeto apto a atendê-lo, determina, continuamente, a aquisição de novos conhecimentos mediadores não apenas da satisfação e atendimento aos motivos existentes, mas, sobretudo, na criação de novas fontes motivadoras ou necessidades socialmente edificadas.

Pode-se dizer que a necessidade, por ser uma construção social e estar em contínuo processo de transformação, não é o ponto de partida da prática educativa, mas sim o seu ponto de chegada. Ou seja, a educação escolar tem de proporcionar as condições para o desenvolvimento de novos interesses, novas necessidades qualitativamente mais elaboradas.

Esse processo aparentemente não estaria atendendo aos interesses do aluno, mas isso é só a aparência, decorrente de se reduzir a visão que se tem do aluno ao indivíduo empírico. Quando se vai além dessa aparência e vê o aluno como indivíduo concreto, compreende-se que o trabalho educativo atende aos interesses do indivíduo aluno na medida em que este, "por sintetizar as relações sociais que caracterizam a sociedade em que vive, seu interesse coincide com a apropriação das objetivações humanas, isto é, o conjunto dos instrumentos materiais e culturais produzidos pela humanidade" (SAVIANI, 2004, p. 49).

A riqueza do ser humano está diretamente ligada às suas necessidades "o homem rico é simultaneamente o homem carente de uma totalidade da manifestação humana de vida. O homem, no qual a sua efetivação própria existe como necessidade (Notwendigkeit) interior, como falta (Not)" (MARX, 2010, p. 112-113, grifos do autor).

A educação escolar é um espaço privilegiado para se provocar nos sujeitos essa carência, essa necessidade de se relacionar com os produtos, materiais e não materiais, que a humanidade já disponibilizou, ocasionando cada vez mais e a ampliação da visão de mundo dos alunos. Percebe-se aí a dialética entre objetivo e subjetivo. A apropriação da riqueza objetiva produzida pela atividade humana por meio da transmissão dos conteúdos artísticos e filosóficos na escola, proporciona o enriquecimento das subjetividades.

Para que isso ocorra faz-se imprescindível a adoção de instrumentos que balizem o trabalho educativo. Em outras palavras, a instrumentalização está relacionada às condições objetivas ofertadas pela instituição escolar a partir das quais o ensino acontece, como por 
exemplo, os materiais, o local em que ocorreu, o número de alunos envolvidos nas ações propostas pelo professor.

O trabalho educativo requer acima de tudo um posicionamento teleológico por parte do professor. Ele deve planejar suas ações de acordo com um objetivo a ser alcançado. A instrumentalização refere-se ao ato de ensino propriamente dito, aos conteúdos devidamente selecionados, graduando a transmissão dos conteúdos de acordo com o nível de aprendizagem dos alunos. O trabalho educativo estruturar-se no sentido de promover as condições adequadas de transmissão do conteúdo aos alunos e isso demanda "[...] dosá-lo e sequenciá-lo de modo que a criança passe gradativamente do seu nãodomínio ao seu domínio" (SAVIANI, 2008, p. 18).

É de posse dos conhecimentos apropriados na escola e disponibilizados pelo professor, mas não de qualquer conhecimento, ou seja, por meio da ciência, da arte e da filosofia em suas formas mais desenvolvidas que os alunos se apropriam das ferramentas necessárias para chegarem à raiz dos problemas sociais.

A questão da instrumentalização deve ser analisada a partir do materialismo histórico-dialético. Nesse sentido, se extrai a ideia de que a pratica educativa deve gerar contradições que levem a um contínuo movimento. Ora é a partir do conhecimento em seus aspectos essenciais que se tem início um movimento paulatino de mudança da visão de mundo do sujeito (catarse).

A catarse refere-se, na educação, a esse rompimento com uma compreensão fetichista e alienada do real aparente e implica uma forma mais rica de relação entre sujeito e a realidade. Essa é a elevação do senso comum à consciência filosófica (SAVIANI, 2007). Pode-se dizer que existe uma diferença qualitativa do processo educativo que se situa antes e depois da catarse.

De todo esse processo há novamente o momento da pratica social. Esta prática social se apresenta, pois, de forma qualitativamente superior à prática social do início do processo educativo, embora os alunos vivam a mesma realidade. Apesar de a prática social do início seja a mesma da prática do final do processo educativo, o que é posto de movimento, em decorrência da aprendizagem, e vai se modificando aos poucos é relação do sujeito com as objetivações humanas mais complexas, criando novas possibilidades de compreensão da realidade social e de atuação na mesma.

\section{Considerações Finais}

Esperamos ter mostrado que tanto as análises de György Lukács sobre as relações entre arte e realidade social, como as análises da pedagogia histórico-crítica sobre as relações entre educação escolar e prática social argumentam pelo caráter fundamentalmente mediado, indireto, dessas relações. A arte atua sobre a subjetividade dos indivíduos e somente dessa forma ela pode exercer alguma influência sobre as decisões que os seres humanos tomam sobre os rumos da sociedade e da vida de cada um. A escola também não transforma diretamente a sociedade, mas atua indiretamente tanto na direção da manutenção como na da transformação do status quo pela via da transformação educativa das consciências, que ocorre pela socialização do saber sistematizado.

Essas intermediações e inter-relações são fundamentais para fortalecermos os laços teóricos e os fundamentos pedagógicos que podem se refletir no interior das salas de aula, na prática dos professores, num ensino mais efetivo, de melhor qualidade, numa aprendizagem mais rica e, consequentemente, em indivíduos mais críticos e em sujeitos potencialmente mais preparados intelectual e sensivelmente para participarem de ações de 
transformação da sociedade, em direção à superação do agônico modo de produção capitalista.

\section{Referências:}

ASSUMPÇÃO, Mariana de Cássia. A prática social na pedagogia histórico-crítica e as relações entre arte e vida em Lukács e Vigotski. 2014. 172 f. Dissertação (Mestrado em Educação Escolar) - Programa de Pós-Graduação em Educação Escolar, Faculdade de Ciências e Letras, Universidade Estadual Paulista, Araraquara, 2014.

BARROCO, Sonia Mari Shima. Vigotski, arte e psiquismo humano: considerações para a psicologia educacional. In: FACCI, Marilda Gonçalves Dias; TULESKI, Silvana Calvo; BARROCO, Sonia Mari Shima (Org.). Escola de Vigotski: contribuições para a psicologia e a educação. Maringá: EDUEM, 2009. p. 107-134.

CHICOTE, Francisco García. Trabalho e arte na estética lukacsiana. In: VAISMAN, Ester; VEDDA, Miguel (Org.). Lukács: estética e ontologia. São Paulo: Alameda, 2014. p. 103121.

DUARTE, Newton. A importância da concepção de mundo para a educação escolar: porque a pedagogia histórico-crítica não endossa o silêncio de Wittgenstein. Germinal: Marxismo e Educação em Debate. Salvador v. 7, n. 1, p. 8-25, 2015. Disponível em: <http://www.portalseer.ufba.br/index.php/revistagerminal/article/view/12808> Acesso em: 14 out. 2016.

DUARTE, Newton. Arte e Formação Humana em Lukács e Vigotski. Anais da 31 Reunião Anual da ANPED. Caxambú, 2008. p.1-14. Disponível em: <http://www.31reuniao.anped.org.br/1trabalho/trabalho17.htm>. Acesso em: 14 out. 2016.

DUARTE, Newton. Ideal e Idealidade em Evald Ilyenkov. Contribuições para a reflexão filosófico-educacional contemporânea. Sociedade do Conhecimento ou Sociedade das Ilusões? Campinas: Autores Associados, 2003, p. 85-102.

DUARTE, Newton. Vigotski e o "aprender a aprender": crítica às apropriações neoliberais e pós-modernas da teoria vigotskiana. Campinas: Autores Associados, 2000.

DUARTE, Newton et al. $\mathrm{O}$ marxismo e a questão dos conteúdos escolares. In: SEMINÁRIO NACIONAL DE ESTUDOS E PESQUISAS: HISTÓRIA, SOCIEDADE E EDUCAÇÃO NO BRASIL, 9., 2012, João Pessoa. História da educação brasileira: experiências e peculiaridades. Anais... Campinas: HISTEDBR, 2012. p. 3953-3979. Disponível em: <http://boletimef.org/biblioteca/3013 >. Acesso em: 14 out. 2016.

FREDERICO, Celso. Marx, Lukács: a arte na perspectiva ontológica. Natal: UFRN, 2005.

GRAMSCI, Antonio. Os intelectuais e a organização da cultura. 4. ed. Rio de Janeiro: Civilização Brasileira, 1982. 
KIRALYFÁLVI, Béla. The Aesthetics of György Lúkacs. Princeton: Princeton University Press, 1975.

KOFLER, Leo; ABENDROTH, Wolfgang; HOLZ, Hans Heinz. Conversando com Lukács. Rio de Janeiro: Paz e Terra, 1969.

KONDER, Leandro. Os marxistas e a arte: breve estudo histórico-crítico de algumas tendências da estética marxista. 2. ed. São Paulo: Expressão Popular, 2013.

LUKÁCS, György. Arte e sociedade: escritos estéticos de 1932-1967. Rio de Janeiro: UFRJ, 2009. Tradução do alemão de: Carlos Nelson Coutinho e José Paulo Netto.

LUKÁCS, Georg. Estetica I: La peculiaridad de lo estetico. v. 1. Cuestiones previas y de princípio. Barcelona: Grijalbo, 1966a. Tradução do alemão de: Manuel Sacristan.

LUKÁCS, Georg. Estetica I: La peculiaridad de lo estetico. v. 2. Problemas de la mímesis. Barcelona: Grijalbo, 1966b. Tradução do alemão de: Manuel Sacristan.

LUKÁCS, Georg. Estetica I: La peculiaridad de lo estetico. v. 3. Categorías básicas de lo estético. Barcelona: Grijalbo, 1967a. Tradução do alemão de: Manuel Sacristan.

LUKÁCS, Georg. Estetica I: La peculiaridad de lo estetico. v. 4. Cuestiones liminares de lo estético. Barcelona: Grijalbo, 1967b. Tradução do alemão de: Manuel Sacristan.

LUKÁCS, Georg. Introdução a uma estética marxista. 2. ed. Rio de Janeiro: Civilização Brasileira, 1970. Tradução do italiano de: Carlos Nelson Coutinho e Leandro Konder.

LUKÁCS, Georg. Materiales sobre el realismo. Barcelona: Grijalbo, 1977. Tradução do alemão de: Manuel Sacristan.

MARTINS, Lígia Márcia. O desenvolvimento do psiquismo e a educação escolar: contribuições à luz da psicologia histórico-cultural e da pedagogia histórico-crítica. Campinas: Autores Associados, 2013.

MARX, Karl. Manuscritos econômico-filosóficos. São Paulo: Boitempo, 2010. Tradução do alemão de: Jesus Ranieri.

SAVIANI, Dermeval. Perspectiva marxiana do problema: subjetividade-intersubjetividade. In: DUARTE, Newton (Org.). Crítica ao fetichismo da individualidade. Campinas: Autores Associados, 2004. p. 21-52.

SAVIANI, Dermeval. Educação: do senso comum à consciência filosófica. 17. ed. rev. Campinas: Autores Associados, 2007.

SAVIANI, Dermeval. Escola e democracia. 41. ed. Campinas: Autores Associados, 2009.

SAVIANI, Dermeval. O Conceito Dialético de Mediação na Pedagogia Histórico-Crítica em Intermediação com a Psicologia Histórico-Cultural. Germinal: Marxismo e Educação em Debate. Salvador, v. 7, n. 1, p. 26-43, 3015. Disponível em: 
$<$ http://www.portalseer.ufba.br/index.php/revistagerminal/article/view/12463> Acesso em: 14 out. 2016.

SAVIANI, Dermeval. Pedagogia histórico-crítica: primeiras aproximações. 10. ed. Campinas: Autores Associados, 2008.

SAVIANI, Dermeval; DUARTE, Newton. Prefácio. In: SAVIANI, Dermeval; DUARTE, Newton (Org.). Pedagogia histórico-crítica e luta de classes na educação escolar. Campinas: Autores Associados, 2012. p. 1-11.

TERTULIAN, Nicolas. Georg Lukács: etapas de seu pensamento estético. São Paulo: UNESP, 2008.

TERTULIAN, Nicolas. A estética de Lukács trinta anos depois. In: PINASSI, Maria Orlanda; LESSA, Sérgio (Org.). Lukács e a atualidade do marxismo. São Paulo: Boitempo, 2002. p. 13-26.

VÁZQUEZ, Adolfo Sánchez. Filosofia da práxis. 2. ed. Rio de Janeiro: Paz e Terra, 1977.

Notas

\footnotetext{
${ }^{1}$ Este artigo é fruto de dissertação de mestrado defendida pela autora, com bolsa da CAPES. A dissertação foi desenvolvida em conexão com a pesquisa "Arte e Formação Humana em Lukács e Vigotski" desenvolvida pelo orientador da dissertação e coautor do artigo, que contou para tanto com bolsa de produtividade em pesquisa do CNPq.

${ }^{2}$ Professora da rede municipal de ensino de Araraquara. Mestre em Educação Escolar pela UNESP, campus de Araraquara. Doutoranda pelo mesmo programa.

${ }^{3}$ Professor Titular do Departamento de Psicologia da Educação, UNESP, campus de Araraquara. Líder do Grupo de Pesquisa "Estudos Marxistas em Educação".

${ }^{4}$ Sobre a relação entre o material e o ideativo, vide Duarte (2003).

Recebido: $\quad$ março-16 $\quad$ Aprovado: setembro-16
} 